\title{
Empirical Model Building and Analysis for Performance of Social Enterprises
}

\author{
Kyung-Soo Lim $^{1^{*}}$ \\ ${ }^{1}$ Department of Industrial and Management Engineering, Daegu University \\ 사회적 기업의 성과분석 실증모델 구축 및 분석 \\ 임경수 $1^{*}$ \\ ${ }^{1}$ 대구대학교 산업경영공학과
}

\begin{abstract}
Social enterprise has been increasingly recognized for as important economic and social contribution to modern society. Recently, many efforts and academic researches related to social enterprise are now emerging from practitioners and academics. This work focused on the key elements affecting the performance of social enterprises such as specifically social entrepreneurship, relationship-oriented organizational culture and government support policy. In this empirical model, two performance variables such as economic and social performance represent the dependent variables. And the size and age of the social enterprises are the controlled variables. By analyzing survey data of 107 social enterprises interesting and meaningful results are obtained. Social entrepreneurship influenced economic and social performance of social enterprises. And relationship-oriented organizational culture influenced economic and social performance of social enterprises. On the other hand, government support policy influenced economic performance of social enterprises, but did not influence its social performance. The developed empirical model of social entrepreneurship in this study showed that community-oriented organizational culture and government policy are important factors for the efficient and successful management of social enterprises in Korea.
\end{abstract}

요 약 사회적 기업은 최근 많은 관심을 받고 있으며 경제 부문에 있어 중요한 경제적 사회적 기여를 하고 있다. 많은 실제적 노력과 학문적 연구를 통하여 그 영역을 넓히고 있는 실정이다. 본 연구에서는 사회적 기업의 성과에 영 향을 미치는 주요 인자들을 설정하였으며 (사회적 기업가정신, 관계지향형 조직문화, 정부지원정책) 사회적 기업의 경 제적 성과와 사회적 성과 두가지 변수를 종속변수로, 그리고 사회적 기업의 규모 및 성숙도를 제어변수로 두었다. 107 개의 사회적기업의 설문조사 데이터를 바탕으로 총 6개의 가설을 검증하여 실제 사회적 기업의 경제적 및 사회적 성과에 기여하는 변수들을 확인할 수 있었다. 본 연구를 통하여 지역밀착형 기업문화와 정부지원정책이 효율적이고 성공적인 사회적기업 성과 창출에 주요한 요소가 됨을 확인할 수 있었다.

Key Words : Empirical analysis, Entrepreneurship, Government support policy, Relationship-oriented culture, Social enterprise

\section{Introduction}

Social enterprises have been recently considered as a promising alternative form of economy because rapid economic development in Korea led to the gap between the rich and the poor. Social enterprise is a certain form of enterprise pursuing social and economical purpose. It willingly responds to social changes especially around the

This work was supported by the Daegu University Research Grant, 2011.

"Corresponding Author : Kyung-Soo Lim(Daegu Univ.)

Tel: +82-53-850-6542 email: kslim@daegu.ac.kr

Received October 29, 2013

Revised (1st January 8, 2014, 2nd February 21, 2014)

Accepted March 6, 2014 
private sector of the welfare state and social organizations. Also, it is characterized by contributing to the promotion of social integration [1]. Many social enterprises in Korea were established by a certification program of the Social Enterprise Promotion Act effective in 2007. For these social enterprises to survive in a competitive environment, it is necessary to answer the following question: What is the success factor for financial or social performance of social enterprise especially in Korea compared to Europe or the United States? In this work, we set the criteria of success of social enterprise in terms of social enterprise's generic or original purpose, i.e. to serve the community and create employment. Three contributing factors are also selected among many determinants of success for enterprise. They are social entrepreneurship, relationship-oriented organizational culture and government support policy. Finally, we construct a model of these factors and their effect on the performance of social enterprise. In this work, empirical research was executed using the survey carried out during November, 2010. We extracted three affecting factors from the theoretical research and made out a structured questionnaire to verify these effects on social enterprises. Then we surveyed 107 businesses among the 355 certified social enterprises in Korea. The remainder of this paper is organized as follows. Some theoretical contents are presented in Section 2. Then results and discussions are given in Section 3 followed by concluding remarks in Section 4.

\section{Theoretical Background}

The "social enterprise" generally represents not-for-profit private organizations providing goods or services directly related to their explicit aim to benefit the community though there is not a unified view about the definition of social enterprise. It depends on dynamics involving various stakeholders in their governing bodies. Social enterprise takes positions at the interception between pure business and traditional non-profit [2]. In the traditional view, the entrepreneur, as the business operator, is the most important element that affects the growth of enterprise.

Some researchers studied the relationship between entrepreneurship and the performance of businesses [3,4]. The results of the researches showed that the individual factors (viz., prior experience, age and personal characteristics of the entrepreneur) have a significant impact on the performance of businesses. In addition, entrepreneurship contributes not only to enhanced organizational performance, but also to the generation of new business which lead to increased profits. Entrepreneurship also helps to obtain a competitive advantage [1].

Social enterprise is an organization created for the purpose of solving social problems. Then, discussing venture business activities and vision sharing are the organization's main objectives. According to Quinn \& Rohrbaugh (1983), an organization with good communication and democratic decision culture can achieve higher organizational performance [5]. Thus analyzing the impact of relationship-oriented organizational culture is important to understand social enterprise. Recently Korean government policy on social enterprise began to formulate. For better operation of social enterprise efficient and effective policy should be set.

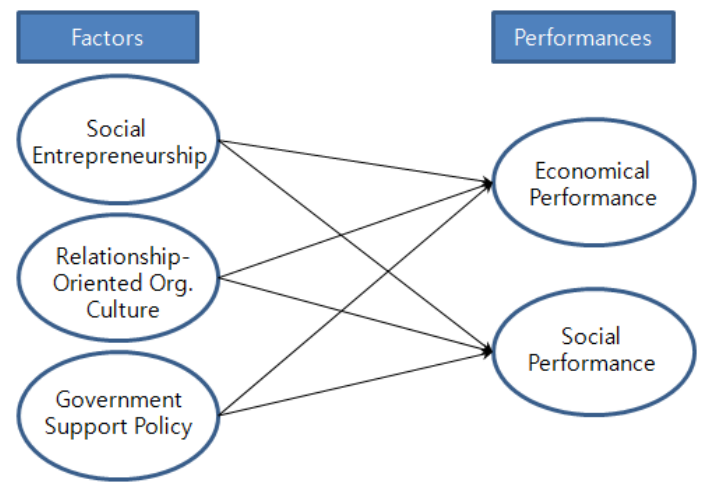

[Fig. 1] Proposed empirical model

The definition of social entrepreneurship can be viewed like: the creation of a social value produced in collaboration with people and organizations from the civil society. Most of peoples are engaged in social innovations that usually imply an economic activity, which is based on four criteria like social values, civil society, innovation, and economic activities. Some researches on the impact factors of social enterprise have been 
performed [6]. In Korea, some research efforts also have been done, but social enterprise is relatively in an early state so that there are no extensive research results.

Sharir \& Lerner (2006) focused on the factors of social enterprise in a fundamental sense [6]. They focused on identifying the factors affecting the success of social enterprises and demonstrate eight factors in the results. The eight variables as contributing to the success of the social ventures are: (1) the entrepreneur's social network; (2) total dedication to the venture's success; (3) the capital base at the establishment stage; (4) the acceptance of the venture idea in the public discourse; (5) the composition of the venturing team, including the ratio of volunteers to salaried employees; (6) forming cooperation in the public and nonprofit sectors in the long-term; (7) the ability of the service to stand the market test; and (8) the entrepreneurs' previous managerial experience. Lee, Kwang Woo (2008) [7] adopted this study as a basis for integrating the successful factors.

\section{Results and Discussions}

Social enterprises are, in general, similar to other non-social enterprises at the incipient period. Thus the elements related to success of general businesses can apply to social enterprises. Entrepreneurship is believed to have a positive effect on the performance of businesses [7]. In view of social entrepreneurship, social enterprise is focusing on both economic and social purpose. In this work, it is assumed that social entrepreneurship somehow affects the success of social enterprise, and the hypotheses are given below.

- Hypothesis 1:

Social entrepreneurship positively affects economic performance of social enterprises.

- Hypothesis 2:

Social entrepreneurship positively affects the social performance of social enterprises.

Relationship-oriented organizational culture have been reported to have significant impacts on overall social enterprise because social enterprise is an organization created for the purpose of solving social problems [Quinn \& Rohrbaugh (1983)]. In a good communication and democratic environment, higher organizational performance can be accomplished in the business. Therefore, following assumptions can be formulated in this study.

\section{Hypothesis 3:}

Relationship-oriented organizational culture positively affects economic performance of social enterprises.

- Hypothesis 4:

Relationship-oriented organizational culture positively affects social performance of social enterprises.

Since Korea's currency crisis, government led a formal study so that its policy on social enterprise began to take shape. Government policy acting on social enterprise is important and effective policy guidance should be set appropriately. In Korea, there are 555 social enterprises in 2011, which are mostly established by a certification program of Social Enterprise Promotion Act. Therefore, in order to promote social enterprise development, the following hypotheses related to the government support policy are made.

Hypothesis 5:

Government support policy positively affects the economic performance of social enterprises.

Hypothesis 6:

Government support policy positively affects the social performance of social enterprises.

As mentioned before, the goal of the research is to identify the three elements that affect the success of social enterprise and to demonstrate a model of the correlation of the elements [Fig. 1]. The elements are social entrepreneurship, relationship-oriented organizational culture, and government support policy. In this model, the three elements become independent variables or factors of the empirical study. On the other hand, the two performance variables such as economic and social performance represent the dependent variables. Here, the size and age of the social enterprises are the controlled variables throughout the study. 
[Table 1] Result of economic performance: standardized beta weights ( $t$ value)

\begin{tabular}{c|c|c|c|c}
\hline \multicolumn{2}{c|}{ Var. } & Model 1 & Model 2 & Model 3 \\
\hline \hline \multirow{3}{*}{ Con } & Size & $0.10(1.01)$ & $0.03(0.33)$ & $0.04(0.45)$ \\
\cline { 2 - 5 } & Age & $-0.07(-0.68)$ & $-0.08(-0.91)$ & $-0.09(-1.03)$ \\
\hline \multirow{3}{*}{ Ind } & Entren. & - & $0.21(2.07)$ & $0.35(1.12)$ \\
\cline { 2 - 5 } & Culture & - & $0.21(2.17)$ & $-0.37(-0.91)$ \\
\cline { 2 - 5 } & Policy & - & $0.25(2.53)$ & $-0.21(-0.41)$ \\
\hline
\end{tabular}

First, reliability for this study was assessed based on Cronbach's alpha [8]. In general, reliability coefficients of Cronbach's alpha around 0.7 are considered good whilst there is strong reliability with coefficients from 0.74 to 0.90 (Nunnally, 1967). Though now shown here, Cronbach's alpha values are good enough, which is given as follows: 0.895 (social entrepreneurship), 0.880 (relationship-oriented organizational culture), 0.735 (government support policy), 0.900 (economical performance), and 0.789 (social performance). On the other hand, validity for this study was assessed based on principal component analysis. In result, these data turned out that there is relative compactness of correlation in the data matrix. It is also able to clarify that factor analysis is highly appropriate for these data.

To prove the hypothesis about the economic performance of this study, we focused on independent variables and executed hierarchical regression analysis. In the first model, enterprise size and age are the control variables and had no effect on the performance of social enterprise. In general, bigger R2 means that the regression model is more suitable [9]. As well, standardized beta coefficient represents the relative effects of independent variables and refers to the size of influence on the dependent variables. The result of the second model showed the impact of social entrepreneurship, relationship-oriented organizational culture, and government support policies regarding economic performance of social enterprise. In particular, social entrepreneurship $(\beta=0.21$, $\mathrm{p}<0.05$ ), and relationship-oriented organizational culture $(\beta=0.21, \quad p<0.05)$ with a confidence level of $95 \%$ appeared to have a statistically significant effect. Furthermore, the government support policy $(\beta=0.25$, $\mathrm{p}<0.01$ ) with a confidence level of $99 \%$ also appeared to have a statistically significant effect. The second model has produced the coefficient of $\mathrm{R}^{2}$ of 0.218 , and it means that the $22 \%$ is the explanatory. Thus, the hypotheses 1 ,
3 , and 5 of this study were accepted. It turned out that the higher the social entrepreneurship means the higher the economic performance. As the relationship-oriented organizational culture is higher, the economic performance of social enterprises is better. In addition, the utilization of government support for the policy results in a better economic performance.

To verify the hypotheses about social performance, similar hierarchical regression analysis was done. In the first model, business size and age are control variables and had no effect on the social performance of social enterprise. The second model was constructed to investigate the impact of social entrepreneurship, relationship-oriented organizational culture, and government support policies on social performance of social enterprise. As a result, social entrepreneurship $(\beta=0.50$, $\mathrm{p}<0.01)$ and relationship-oriented organizational culture $(\beta$ $=0.23, \quad \mathrm{p}<0.01$ ) with $99 \%$ confidence level showed statistically significant effects. However, the government support policy showed no statistically significant relationship with social performance of social enterprise. R2 of the second model was found to be 0.459 , which means the $46 \%$ explanatory power. In result, the hypotheses 2 and 4 were accepted with the rejection of hypothesis 6. It means that the higher the social entrepreneurship, the greater social performance of social enterprises. Also, the more developed a relationship-oriented organizational culture, the greater social performance of social enterprises. On the other hand, the government support policies had no significant correlation with the performance of social enterprises.

[Table 2] Result of social performance: standardized beta weights ( $t$ value)

\begin{tabular}{c|c|c|c|c}
\hline \multicolumn{2}{|c|}{ Var. } & Model 1 & Model 2 & Model 3 \\
\hline \hline \multirow{2}{*}{ Con } & Size & $0.08(0.76)$ & $0.03(0.35)$ & $0.03(0.39)$ \\
\cline { 2 - 5 } & Age & $-0.05(-0.53)$ & $-0.05(-0.61)$ & $-0.04(-0.55)$ \\
\hline \multirow{3}{*}{ Ind } & Entren. & - & $0.50(5.72)$ & $0.33(1.24)$ \\
\cline { 2 - 5 } & Culture & - & $0.23(2.80)$ & $-0.13(-0.37)$ \\
\cline { 2 - 5 } & Policy & - & $0.11(1.24)$ & $-0.54(-1.20)$ \\
\hline
\end{tabular}

This study investigated and analyzed the effects of the three independent variables (i.e., social entrepreneurship, relationship-oriented organizational culture, and government support policy) on the two performance measures of social enterprises (i.e., economic and social 
performance). The results of the empirical model are summarized.

The hypothesis related to the impact of social entrepreneurship on the performance of social enterprises was accepted in this study, which is similar to those of previous results $[1,3]$. Furthermore, the risk management behavior by social entrepreneurs is distinct from entrepreneurial risk-taking orientation. The enhanced social entrepreneurship can facilitate corporation's achievement both in the economical and social performance. Second, the hypothesis related to relationship-oriented organizational culture was also accepted to be statistically significant. Thus, the organizational culture affects the success of social enterprise. When the social enterprise tries to adopt democratic decision-making processes, it will achieve both economical and social performances.

This culture will contribute to the formation of a network that for-profit companies cannot be achieved in. The government support policies for social enterprises have an impact on the economical performance, but has no impact on the social performance of social enterprise. It means that the more frequent the utilization of government support policies, the higher the economic performance. However, government support policy for social enterprise does not have a direct impact on the social performance of social enterprise.

[Table 3] Hypothesis results

\begin{tabular}{c|l|c}
\hline No. & \multicolumn{1}{|c|}{ Hypothesis } & Result \\
\hline \hline 1 & Social entrepren. $\rightarrow$ economic performance & accept \\
\hline 2 & Social entrepren. $\rightarrow$ social performance & accept \\
\hline 3 & Organ. culture $\rightarrow$ economic performance & accept \\
\hline 4 & Organ. culture $\rightarrow$ social performance & accept \\
\hline 5 & Government policy $\rightarrow$ economic performance & accept \\
\hline 6 & Government policy $\rightarrow$ social performance & reject \\
\hline
\end{tabular}

\section{Concluding Remarks}

This work focused on the identification of key elements affecting the performance of social enterprises, viz., social entrepreneurship, relationship-oriented organizational culture and government support policy.
Based on survey data of 107 social enterprises interesting and meaningful results are obtained. Social entrepreneurship influenced economic and social performance of social enterprises. And relationship-oriented organizational culture influenced economic and social performance of social enterprises. On the other hand, government support policy influenced economic performance of social enterprises, but did not influence its social performance. This study has advanced research in social entrepreneurship and contributed to the development of an empirically derived model of social entrepreneurship. It also helps to identify the core behavioral dimensions of innovativeness, pro-activeness, risk management, etc. It also indicates that the community-oriented organizational culture and the government policy become important factors in achieving the successful management performance of social enterprises. Considering the status of social enterprise recognized for as its economic and social contribution to society, this work can be one of building blocks to be used for understanding social enterprise.

\section{References}

[1] J. Weerawardena, G. S. Mort, "Investigating social entrepreneurship: A multidimensional model", Journal of World Business, 41(1), pp. 21-35, 2006.

DOI: http://dx.doi.org/10.1016/j.jwb.2005.09.001

[2] K. Alter, "Social enterprise typology", Virtue Ventures LLC, 2007.

[3] C. C. Chen, P. G. Greene, A. Crick, " Does entrepreneurial self-efficacy distinguish entrepreneurs from managers?", Journal of Business Venturing 13(4), pp. 295 - 316, 1998.

DOI: http://dx.doi.org/10.1016/S0883-9026(97)00029-3

[4] R. A. Baron, "Psychological Perspectives on Entrepreneurship: Cognitive and Social Factors in Entrepreneurs' Success", Current Directions in Psychological Science, 9(1), pp. 15-18, 2000. DOI: http://dx.doi.org/10.1111/1467-8721.00050

[5] R. E. Quinn, J. Rohrbaugh, "A Spatial Model of Effectiveness Criteria: Towards a Competing Values Approach to Organizational Analysis", Management Science, 29(3), pp. 363-377, 1983.

DOI: http://dx.doi.org/10.1287/mnsc.29.3.363

[6] M. Sharir, M. Lerner, "Gauging the success of social 
ventures initiated by individual social entrepreneurs", Journal of World Business, 41, pp. 6-20, 2006.

DOI: http://dx.doi.org/10.1016/j.jwb.2005.09.004

[7] Y. S. Kim, K. W. Lee, J. H. Kwon, “An Exploratory Research on the Social Enterprise for Local Economic Activation: Focus on Community Business", Knowledge Management Research, 9, pp. 77-96, 2008.

[8] G. T. Lumpkin, G. G. Dess, "Clarifying the Entrepreneurial Orientation Construct and Linking It to Performance", The Academy of Management Review, 21, pp. 135-172, 1996.

DOI: http://dx.doi.org/10.2307/258632

[9] G. S. Mort, J. Weerawardena, K. Carnegie, "Social entrepreneurship: Towards Conceptualization," International Journal of Nonprofit and Voluntary Sector Marketing, 8, pp. $76-88,2003$.

DOI: http://dx.doi.org/10.1002/nvsm.202

\section{Kyung-Soo Lim [Regular member]}

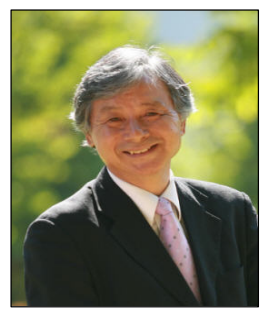

- Feb. 1973 : YeungNam Univ., Business Administration, MS

- Feb. 1975 : YeungNam Univ., Business Administration, $\mathrm{PhD}$

- Mar. $1981 \sim$ current : Daegu Univ., Dept. of Ind. \& Mng. Eng. Professor

$<$ Research Interests $>$

Quality Engineering, Quality Management 